\title{
Managed Care and Primary Physician Satisfaction
}

\author{
David Grembowski, PhD, Cornelia M. Ulrich, PhD, David Paschane, MS, \\ Paula Diehr, PhD, Wayne Katon, MD, Diane Martin, PhD, \\ Donald L. Patrick, PhD, MSPH, and Christine Velicer, MS
}

Background: We examined whether physician compensation, financial incentives, and care management tools were associated with primary physician job and referral satisfaction. Our study was guided by a conceptual model of physician satisfaction derived from published evidence.

Methods: A cross-sectional survey was performed of 495 primary physicians (family practitioners, general practitioners, general internists) in the Seattle metropolitan area in 1997.

Results: Bivariate analyses revealed that salary compensation, productivity bonuses, and withholds for referrals were associated with job and referral dissatisfaction. However, after controlling for physician, practice, and office characteristics, only the association between salary payment and job dissatisfaction remained significant. Practice in offices with more physicians had the strongest association with physician job dissatisfaction.

Conclusions: Although managed care features are correlated with physician job and referral dissatisfaction, the source of dissatisfaction may originate from being an employed physician in a large medical group with more physicians, which may be more likely to impose bureaucratic controls that limit physician autonomy. (J Am Board Fam Pract 2003;16:383-93.)

Many physicians believe that managed care and market competition have eroded their satisfaction with medical practice. ${ }^{1-9}$ Sources of physician dissatisfaction include loss of autonomy, increase in administrative burdens, potential loss of patients and income, greater time pressures, and threats of malpractice litigation. ${ }^{4,10-12}$

Physician satisfaction is important because it contributes to the quality of health care. Previous studies indicate that greater physician satisfaction is associated with appropriate prescribing practices, ${ }^{13}$ patient adherence, ${ }^{14}$ and greater patient satisfaction. ${ }^{15,16}$ Physician satisfaction also results in less turnover, which contributes to patients' continuity of care, patient satisfaction and retention, and lower administrative costs of recruiting and replacing physicians. ${ }^{17,18}$ Dissatisfied physicians also may

Submitted 2 August 2002

From the Center for Cost and Outcomes Research (DG, PD, DM, DLP) and the Departments of Health Services (DG, CMU, PD, DM, DLP), Biostatistics (PD), Psychiatry (WK), Epidemiology (CMU, CV), and Geography (DP), University of Washington, Seattle, and the Cancer Prevention Research Program, Fred Hutchinson Cancer Research Center, Seattle, Washington (CMU). Address correspondence to David Grembowski, PhD, Department of Health Services, University of Washington, 1959 NE Pacific Street, Box 357660, Seattle, Washington 98195-7660 (e-mail: grem@u.washington.edu).

This work was supported by grant HS11712 from the Agency for Healthcare Research and Quality. have more costly practice styles, generating more outpatient procedures and referrals. ${ }^{12}$ Because of these associations, provider satisfaction is regarded as 1 of the 4 critical outcomes of health care, along with health status, patient satisfaction, and cost. ${ }^{19}$

However, other studies report contradictory evidence about the relationship between managed care and physician satisfaction. For young physicians, managed care is not uniformly associated with less satisfaction. ${ }^{20,21}$ In 2 studies, HMO physicians had similar or greater satisfaction than physicians in fee-for-service practice, ${ }^{22,23}$ possibly because the clinical autonomy and income of the HMO physicians was satisfactory. ${ }^{3,9,18,23}$

Given the mixed evidence about the relationship between managed care and physician satisfaction, our aim was to determine whether physician compensation, financial incentives, and care management tools are associated with primary physician satisfaction. A related aim was to determine whether physician, practice, and office characteristics have stronger or weaker associations with primary physician satisfaction than managed care features.

\section{Conceptual Model}

Figure 1 presents the conceptual model guiding our analysis of managed care and physician satisfaction, 


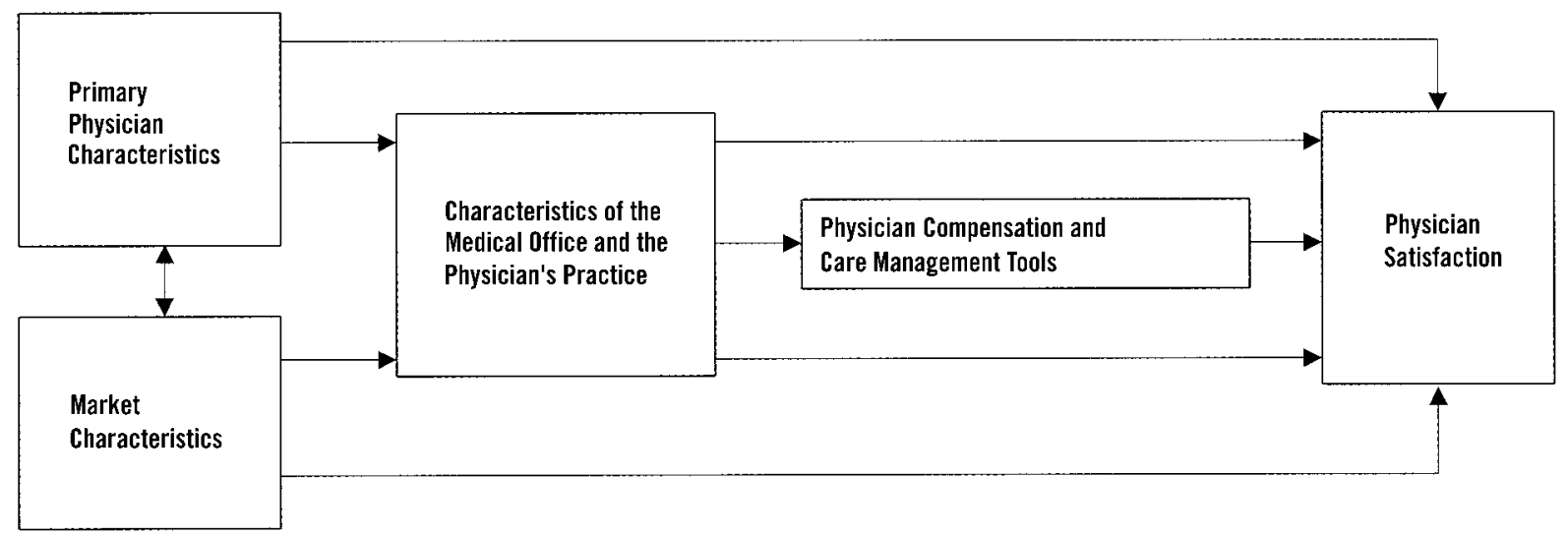

Figure 1. Conceptual model of physician satisfaction. Examples of primary physician characteristics include sex, specialty, board certification, and years in practice. Examples of market characteristics include the presence of managed health plans, penetration, and uninsured rate.

derived from Blumenthal et $\mathrm{al}^{24}$ and Hadley et $\mathrm{al}^{5}$ The figure itself is an extension of Reschovsky et al's $^{25}$ framework for examining managed care effects on physician perceptions of quality.

Reviewing Figure 1, the model posits that primary physician satisfaction is determined directly and indirectly by the characteristics of the market in which physicians practice, the characteristics of the primary physician, and the characteristics of the physician's primary care office and its compensation and care management tools. A central assumption of the model is that primary physicians are not randomly allocated across primary care offices; rather, they select the offices in which they prefer to practice. In general, physicians seek offices having the right "balance" of bureaucratic autonomy (control over patient selection and time allocation) and clinical autonomy (control over patient care decisions). ${ }^{21,26,27}$ Some physicians prefer small, independent offices where they have both clinical and bureaucratic autonomy. Other physicians value larger group offices that have some bureaucratic structure, but doctors still control the use of tests and treatment selection. Physicians also tend to be more satisfied when their practices have fewer patients, less time pressure and stress, and greater resources. $^{2,3,10,12,28-33}$

The choice of medical office largely determines physician compensation and the office's tools for managing care, which are the "managed care features" of the model (see Figure 1). Physicians are more satisfied if compensated appropriately, ${ }^{28,32}$ although Williams et $\mathrm{al}^{30}$ found that income was unrelated to satisfaction. Physicians paid by salary were more dissatisfied than physicians paid by some form of fee-for-service, ${ }^{11}$ and physician payment based on productivity also was associated with dissatisfaction. ${ }^{30,34}$ Similarly, practice guidelines and protocols, which tend to be more common in $\mathrm{HMOs}$, are associated with dissatisfaction, ${ }^{20}$ and the same relationship applies to financial and other incentives to reduce services. ${ }^{5,35}$ Physicians in medical groups with utilization management that restricts their autonomy were dissatisfied with patient care. ${ }^{4}$ These findings indicate that appropriate compensation and less managed care are associated generally with greater satisfaction.

We applied the model in Figure 1 to examine the associations between managed care and job and referral satisfaction among family physicians, general internists, and general practitioners in the Seattle metropolitan area.

\section{Methods \\ Population}

As part of our larger Physician Referral Study, ${ }^{36,37}$ we invited 832 primary physicians (family practitioners, general internists, and general practitioners) in private practice at least $50 \%$ of the time in the Seattle metropolitan area in 1997 to participate in the study. Of these, 261 physicians (31\%) in 72 offices consented to participate. Participating physicians and a random sample of the primary physicians who did not participate $(\mathrm{n}=300)$ were asked to complete self-administered questionnaires, which is the data source for this cross-sectional study. 


\begin{tabular}{lr}
\hline Criteria & Average \\
\hline Physician Job Satisfaction & $4.44(0.63)$ \\
The care you provide to your patients & $3.65(1.05)$ \\
The degree of personal autonomy you have & $3.22(1.21)$ \\
The way you are paid for your services & $3.56(1.05)$ \\
The current volume of patients that you see & $3.30(1.12)$ \\
The way that your practice is managed & $3.71(1.03)$ \\
Your current work setting overall & $3.65(0.73)$ \\
Scale Score & $3.62(0.90)$ \\
Physician Referral Satisfaction & $3.70(0.98)$ \\
Your ability to retain control over the patients' care after referral to specialist & $3.76(0.87)$ \\
Your ability to refer patients to the specialists who are best suited to help them & $3.69(0.73)$ \\
Your communication with specialists regarding outcomes of patients referrals & \\
Scale Score &
\end{tabular}

For each item, physicians rated their satisfaction on a scale of 1 (very dissatisfied) to 5 (very satisfied). Standard deviation presented in parentheses.

\section{Measures}

Measures were chosen for 4 of the 5 components in the conceptual model (see Figure 1). Market characteristics were not measured because the study was conducted in a single market. The Seattle market had a relatively balanced mix of HMO, point-ofservice, preferred provider organization, and feefor-service health plans. ${ }^{37,38}$

\section{Primary Physician Characteristics}

Physician characteristics included gender, years in practice, and whether the physician was white or not. Specialty and board certification were measured using the American Medical Association Physician Masterfile. ${ }^{39}$ Physicians rated their tolerance for uncertainty in patient care by indicating agreement or disagreement with 2 statements: "the uncertainty of patient care often troubles me" and "uncertainty in patient care makes me uneasy." 40 Scores ranged from 2 to 8 , where 8 indicates strong disagreement (ie, greater tolerance for uncertainty).

\section{Medical Office and Physician Practice Characteristics}

Office characteristics included office type (solo, primary group, or multispecialty group practice), the number of physicians in the office, and whether the office was owned privately. Physicians also rated how difficult or easy it was to refer a patient to a specialist on a 1-to-5 scale, where "1" indicates very difficult and " 5 " indicates very easy.

Physician workload was measured by patient visits per hour, administrative hours per week, and percentage of patients referred in a typical month. Patient mix was measured by the percentages of patients who were female, nonwhite, aged 18 and under, aged 65 and above, and from middle- or upper-class households.

Physician Compensation, Financial Incentives, and Care Management Tools

Physician compensation was measured by whether the physician was paid by salary or some form of fee-for-service. Financial incentives included whether the physician received a productivity bonus and had a financial withhold for referrals. Care management was measured in the following areas: financial risk (percentage of HMO patients in physician's practice), utilization review (office prior approval required before referring patient to specialist inside or outside the office), and clinical guidelines (office follows written clinical guidelines for treating specific conditions or written referral guidelines for specific conditions).

\section{Physician Satisfaction}

Primary physician job satisfaction was measured with a 6-item scale adapted from adapted from Greenfield et $a{ }^{4},{ }^{41}$ and physician satisfaction with referrals was measured with a 3 -item scale adapted from Shortell ${ }^{42}$ and Roulidis and Schulman, ${ }^{43}$ (Table 1). We measured physician satisfaction with referrals because referrals are part of everyday practice, a target of managed care controls, and a focus of our larger study. For each item, physicians rated their satisfaction on a scale of 1 (very dissatisfied) to 5 (very satisfied). Factor analysis of the 9 items revealed 2 groups consistent with the 2 scales. A physician's job satisfaction was measured by averaging the 6 items in the scale, and physician referral satisfaction was defined the same way for the 
3 -item scale. The scales were correlated moderately $(r=0.37 ; P=.001)$, indicating the scales measured different dimensions of satisfaction.

The physician job satisfaction scores had predictive validity. Physician satisfaction was measured in 1997; between 1997 and Fall 2000, we sent participating physicians periodic newsletters about the findings of the Physician Referral Study. The US Postal Service returned newsletters as "undeliverable/no forwarding address" for 44 physicians, which indicated physician turnover. We hypothesized that these physicians left their offices partly because of low job satisfaction., ${ }^{3,44}$ Analysis of variance (ANOVA) revealed that physicians who left their offices had less job satisfaction at baseline (3.39 average index score) than physicians who still received mail at office addresses (3.69 average index score; $P=.016$ ).

\section{Data Collection}

Data collection protocols were approved by the Human Subjects' Internal Review Board at the University of Washington. The questionnaire survey was performed using methods developed by Dillman. ${ }^{45,46}$ The questionnaire, cover letter containing the elements of informed consent, postagepaid return envelope, and \$20 incentive were inserted into a University of Washington "Husky" folder, and a token gift of appreciation was attached with ribbon to each folder. Study staff delivered the folders in person to the offices of participating and sampled nonparticipating primary physicians in the Seattle area. Nonrespondent physicians were sent a replacement questionnaire. Physicians who did not complete the replacement questionnaire were contacted by staff through telephone or fax to answer any questions about the study and draw their attention to the questionnaire.

\section{Data Analysis}

Bivariate ANOVA tests were computed to determine whether each physician, practice, office, compensation, and care management variable was associated significantly with physician job and referral satisfaction. For continuous variables, ANOVA tests were performed by dividing the distribution at the median.

Because associations between the care management variables and physician satisfaction could be caused by other variables in our conceptual model, multivariable statistical tests were conducted using partial correlation analysis. In the first analysis, we calculated the correlation between physician job satisfaction and each practice, office, compensation, and care management variable, controlling for physician characteristics. In the second analysis, we computed the correlation between physician job satisfaction and each office, compensation, and care management variable, controlling for physician and practice characteristics. Third, we computed the correlation between physician job satisfaction and each compensation and care management variable, controlling for physician, practice, and office characteristics. Fourth, we examined the partial correlation between physician job satisfaction and each physician, office, or care management characteristic, this time controlling for all other variables. Finally, we repeated these analyses for physician referral satisfaction.

We conducted both unweighted and weighted analyses based on the sampling fractions of the participating and nonparticipating physicians. Because the results were very similar, we present only the unweighted findings.

\section{Results}

About $97 \%$ of the participating physicians ( $\mathrm{n}=$ 252) completed the self-administered questionnaire, and $81 \%$ of the randomly sampled, nonparticipating physicians $(n=243)$ completed their questionnaires. Results are based on 495 physician questionnaires. Physicians tended to be male, white, board-certified, and family practitioners (61\%; Table 2). No statistically significant differences were detected between the job and referral satisfaction of participating versus nonparticipating physicians.

\section{Physician Job Satisfaction}

Physician Compensation, Financial Incentives, and Care Management Tools

Bivariate results in Table 2 indicate that physicians were more dissatisfied when they were paid by salary than by fee-for-service, were paid a productivity bonus, and had a financial withhold for referrals. However, in multivariable models controlling for physician, office, and practice characteristics, only being a salaried employee was associated significantly with dissatisfaction across models (Table 3 , top row). 


\begin{tabular}{|c|c|c|c|}
\hline Characteristics & $\begin{array}{l}\text { Sample } \\
\text { Size }\end{array}$ & $\begin{array}{c}\text { Average Physician } \\
\text { Job Satisfaction }\end{array}$ & $\begin{array}{l}\text { Average Physician } \\
\text { Referral Satisfaction }\end{array}$ \\
\hline \multicolumn{4}{|l|}{ Physician Characteristics } \\
\hline \multicolumn{4}{|l|}{ Gender } \\
\hline Male & 321 & $3.72(0.69)^{* *}$ & $3.74(0.69)$ \\
\hline Female & 177 & $3.53(0.79)$ & $3.62(0.79)$ \\
\hline \multicolumn{4}{|l|}{ Race } \\
\hline White & 425 & $3.68(0.72)^{*}$ & $3.70(0.73)$ \\
\hline Nonwhite & 65 & $3.43(0.73)$ & $3.61(0.72)$ \\
\hline \multicolumn{4}{|l|}{ Specialty } \\
\hline Family practice & 300 & $3.66(0.70)$ & $3.69(0.72)$ \\
\hline Internal medicine & 163 & $3.60(0.77)$ & $3.65(0.77)$ \\
\hline General practice & 30 & $3.68(0.83)$ & $3.94(0.58)$ \\
\hline \multicolumn{4}{|l|}{ Board-certified } \\
\hline Yes & 343 & $3.63(0.76)$ & $3.72(0.75)$ \\
\hline No & 125 & $3.65(0.70)$ & $3.63(0.65)$ \\
\hline \multicolumn{4}{|l|}{ Years in Practice } \\
\hline$<15$ years & 229 & $3.56(0.74)^{*}$ & $3.57(0.75)^{* *}$ \\
\hline$\geq 15$ years & 243 & $3.70(0.74)$ & $3.82(0.69)$ \\
\hline \multicolumn{4}{|c|}{ Tolerance for uncertainty in patient care (range, $0-8$ ) } \\
\hline$<5$ & 158 & $3.49(0.70)^{* *}$ & $3.54(0.69)^{* *}$ \\
\hline$\geq 5$ & 332 & $3.74(0.73)$ & $3.78(0.72)$ \\
\hline \multicolumn{4}{|c|}{ Physician Practice Characteristics } \\
\hline \multicolumn{4}{|c|}{ Patient visits per hour } \\
\hline$<2.5$ & 219 & $3.63(0.75)$ & $3.65(0.80)$ \\
\hline$\geq 2.5$ & 276 & $3.66(0.72)$ & $3.73(0.67)$ \\
\hline \multicolumn{4}{|c|}{ Administrative hours per week } \\
\hline$<8$ & 220 & $3.77(0.73)^{* *}$ & $3.77(0.76)^{*}$ \\
\hline$\geq 8$ & 269 & $3.55(0.72)$ & $3.62(0.70)$ \\
\hline \multicolumn{4}{|c|}{ Percentage patients referred per month } \\
\hline$<10$ & 173 & $3.77(.072)^{* *}$ & $3.73(0.79)$ \\
\hline$\geq 10$ & 322 & $3.58(0.73)$ & $3.67(0.70)$ \\
\hline \multicolumn{4}{|c|}{ Percentage female patients } \\
\hline$<60$ & 198 & $3.66(0.66)$ & $3.75(0.71)$ \\
\hline$\geq 60$ & 298 & $3.64(0.77)$ & $3.67(0.74)$ \\
\hline \multicolumn{4}{|c|}{ Percentage nonwhite patients } \\
\hline$<10$ & 144 & $3.70(0.71)$ & $3.77(0.75)$ \\
\hline$\geq 10$ & 351 & $3.63(0.74)$ & $3.66(0.72)$ \\
\hline \multicolumn{4}{|c|}{ Percentage patients $\leq 18$ years } \\
\hline$<15$ & 245 & $3.65(0.76)$ & $3.71(0.75)$ \\
\hline$\geq 15$ & 251 & $3.66(0.69)$ & $3.69(0.71)$ \\
\hline Percentage patients & & & \\
\hline$<20$ & 166 & $3.67(0.71)$ & $3.65(0.76)$ \\
\hline$\geq 20$ & 330 & $3.64(0.74)$ & $3.72(0.71)$ \\
\hline Percentage patients & & & \\
\hline$<60$ & 184 & $3.55(0.72)^{*}$ & $3.61(0.74)$ \\
\hline$\geq 60$ & 308 & $3.71(0.73)$ & $3.74(0.72)$ \\
\hline Office Characteristics & & & \\
\hline Office type & & & \\
\hline Solo Primary & 76 & $3.82(0.66)^{* *}$ & $3.85(0.62)^{*}$ \\
\hline Group Primary & 246 & $3.55(0.78)$ & $3.64(0.75)$ \\
\hline Multi-specialty & 155 & $3.72(0.66)$ & $3.74(0.70)$ \\
\hline Number of provider & & & \\
\hline$<8$ & 227 & $3.74(0.66)^{*}$ & $3.69(0.70)$ \\
\hline$\geq 8$ & 270 & $3.57(0.78)$ & $3.70(0.76)$ \\
\hline Private Ownership & & & \\
\hline Yes & 298 & $3.73(0.70)^{* *}$ & $3.73(0.70)^{* *}$ \\
\hline No & 167 & $3.50(0.70)$ & $3.50(0.76)$ \\
\hline Difficulty/ease of ref & & & \\
\hline 1 Very difficult & 9 & $2.88(0.95)^{* *}$ & $3.00(0.67)^{* *}$ \\
\hline 2 & 75 & $3.48(0.72)$ & $3.32(0.84)$ \\
\hline 3 & 170 & $3.55(0.72)$ & $3.57(0.64)$ \\
\hline 4 & 144 & $3.72(0.72)$ & $3.74(0.68)$ \\
\hline 5 Very easy & 96 & $3.90(0.66)$ & $4.20(0.54)$ \\
\hline Compensation and Car & & & \\
\hline Type of Compensati & & & \\
\hline Salary & 319 & $3.56(0.77)^{* *}$ & $3.68(0.74)$ \\
\hline Fee-for-service & 170 & $3.83(0.63)$ & $3.72(0.73)$ \\
\hline
\end{tabular}




\begin{tabular}{|c|c|c|c|}
\hline Characteristics & $\begin{array}{l}\text { Sample } \\
\text { Size }\end{array}$ & $\begin{array}{l}\text { Average Physician } \\
\text { Job Satisfaction }\end{array}$ & $\begin{array}{l}\text { Average Physician } \\
\text { Referral Satisfaction }\end{array}$ \\
\hline \multicolumn{4}{|c|}{ Productivity bonus } \\
\hline Yes & 260 & $3.54(0.79)^{\star *}$ & $3.62(0.71)$ \\
\hline No & 238 & $3.78(0.65)$ & $3.78(0.75)$ \\
\hline \multicolumn{4}{|c|}{ Percentage patients in HMOs } \\
\hline$<20$ & 166 & $3.74(0.73)$ & $3.65(0.73)$ \\
\hline$\geq 20$ & 274 & $3.61(0.73)$ & $3.76(0.70)$ \\
\hline \multicolumn{4}{|c|}{ Financial withhold for referrals } \\
\hline Yes & 137 & $3.50(0.74)^{* *}$ & $3.47(0.72)^{* *}$ \\
\hline No & 361 & $3.71(0.73)$ & $3.78(0.72)$ \\
\hline \multicolumn{4}{|c|}{$\begin{array}{l}\text { Office prior approval required to refer to specialist } \\
\text { inside the office }\end{array}$} \\
\hline Yes & 119 & $3.65(0.73)$ & $3.80(0.69)$ \\
\hline No & 379 & $3.65(0.74)$ & $3.66(0.74)$ \\
\hline \multicolumn{4}{|c|}{$\begin{array}{l}\text { Office prior approval required to refer to specialist } \\
\text { outside the office }\end{array}$} \\
\hline Yes & 270 & $3.58(0.76)^{*}$ & $3.73(0.75)$ \\
\hline No & 228 & $3.74(0.69)$ & $3.65(0.71)$ \\
\hline \multicolumn{4}{|c|}{ Office follows written referral guidelines } \\
\hline Yes & 196 & $3.63(0.76)$ & $3.73(0.73)$ \\
\hline No & 302 & $3.66(0.71)$ & $3.67(0.73)$ \\
\hline \multicolumn{4}{|c|}{$\begin{array}{l}\text { Office follows written clinical guidelines for treating } \\
\text { specific conditions }\end{array}$} \\
\hline Yes & 177 & $3.65(0.73)$ & $3.75(0.77)$ \\
\hline No & 321 & $3.65(0.74)$ & $3.67(0.71)$ \\
\hline
\end{tabular}

Bivariate tests used analysis of variance. For continuous variables, statistical tests were performed by dividing the distribution at the median.

${ }^{*} P<.05$.

${ }^{* *} P<.01$

Of the care management variables, bivariate results indicate that physicians were more dissatisfied when their offices required prior approval to refer to specialists outside the office (Table 2). However, this association disappeared when controlling for other characteristics (Table 3).

\section{Physician Characteristics}

Bivariate analyses indicate that physicians had greater job satisfaction if they were male, white, had less than 15 years of practice, and had greater tolerance for clinical uncertainty (Table 2). However, in multivariable analyses, tolerance for uncertainty was the only characteristic associated with greater job satisfaction (Table 3).

\section{Practice Characteristics}

Bivariate results reveal that physicians had greater job satisfaction if they worked fewer administrative hours, referred fewer patients, had more patients from middle- and upper-class households, and had fewer nonwhite patients (Tables 2 and 3). In multivariable analyses, only a single characteristic, fewer administrative hours, was associated consistently with greater satisfaction across models (Table 3).

\section{Office Characteristics}

In bivariate analyses, job satisfaction was highest for solo physicians, lowest for primary group physicians, and fell in between for physicians in multispecialty groups. Physicians were more satisfied in privately owned offices, in offices with fewer physicians, and offices in which it was easy to refer (Table 2). Controlling for physician and practice characteristics, the same associations were found. In multivariable analyses that controlled for all other variables (Table 3, right column), only 2 associations were found: fewer physicians in the office and ease of referral were associated with greater job satisfaction (partial $r=-.24$ and 0.20 , respectively). The smaller number of associations may be a result of correlations among the office characteristics (for example, multispecialty group practices generally had more physicians than other practices).

\section{Physician Referral Satisfaction}

Physician Compensation, Financial Incentives, and Care Management Tools

In bivariate analyses, physicians who had a financial withhold for referrals were more dissatisfied with 


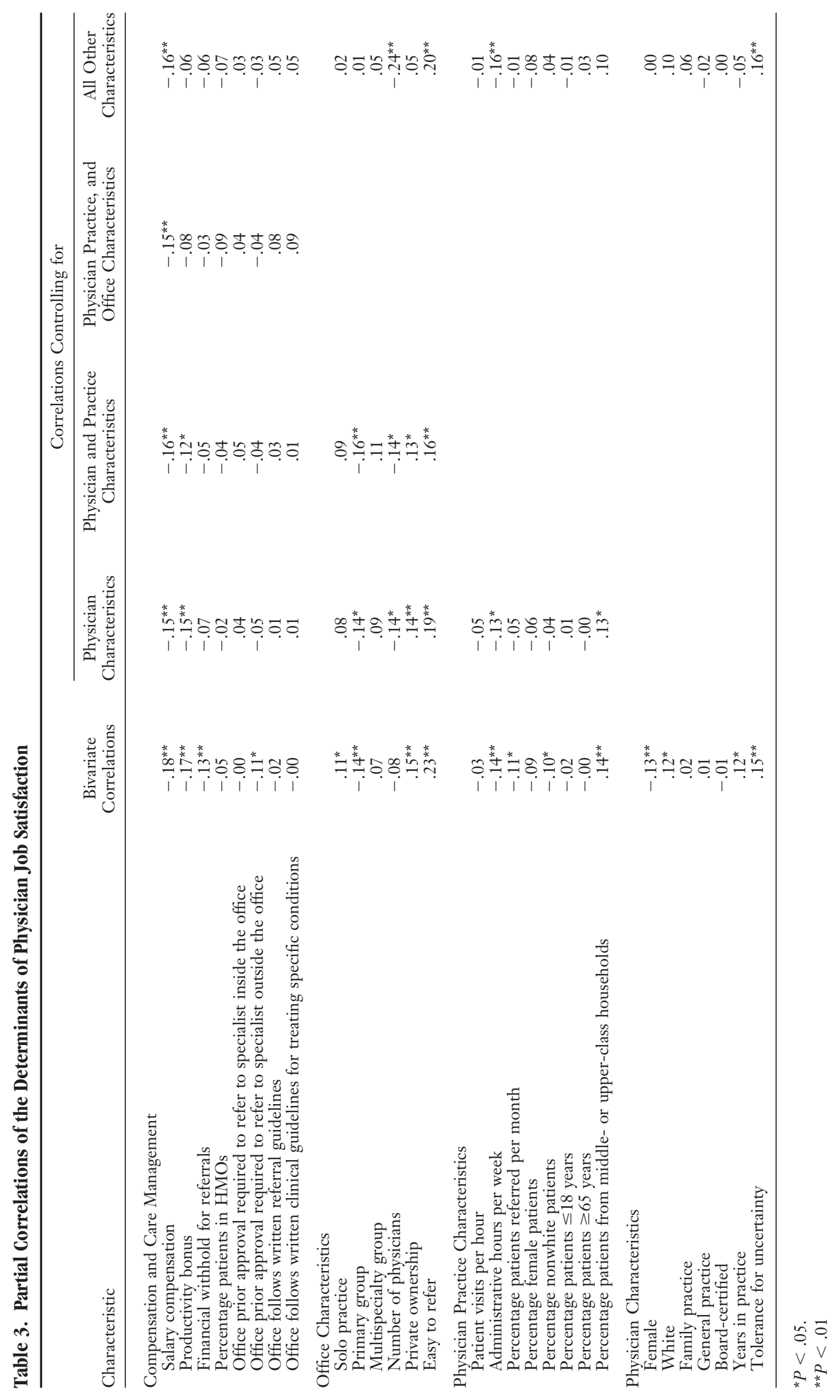




\begin{tabular}{|c|c|c|c|c|c|}
\hline \multirow[b]{2}{*}{ Characteristic } & \multirow[b]{2}{*}{$\begin{array}{c}\text { Bivariate } \\
\text { Correlations }\end{array}$} & \multicolumn{4}{|c|}{ Correlations Controlling for } \\
\hline & & $\begin{array}{l}\text { Physician } \\
\text { Characteristics }\end{array}$ & $\begin{array}{l}\text { Physician } \\
\text { and Practice } \\
\text { Characteristics }\end{array}$ & $\begin{array}{c}\text { Physician } \\
\text { Practice, and } \\
\text { Office Characteristics }\end{array}$ & $\begin{array}{l}\text { All Other } \\
\text { Characteristics }\end{array}$ \\
\hline \multicolumn{6}{|l|}{ Compensation and Care Management } \\
\hline Salary compensation & -.03 & .05 & .02 & .04 & -.00 \\
\hline Productivity bonus & $-.10^{*}$ & -.05 & -.08 & -.02 & -.01 \\
\hline Financial withhold for referrals & $-.19^{* *}$ & $-.17^{\text {** }}$ & $-.14^{*}$ & -.08 & -.08 \\
\hline Percentage patients in HMOs & $.18^{* *}$ & $.20^{* *}$ & $.19^{* *}$ & .08 & .06 \\
\hline $\begin{array}{l}\text { Office prior approval required to } \\
\text { refer to specialist inside the } \\
\text { office }\end{array}$ & .08 & .06 & -.05 & -.01 & -.04 \\
\hline $\begin{array}{l}\text { Office prior approval required to } \\
\text { refer to specialist outside the } \\
\text { office }\end{array}$ & .05 & .11 & -.07 & .02 & .02 \\
\hline $\begin{array}{l}\text { Office follows written referral } \\
\text { guidelines }\end{array}$ & .04 & .06 & -.05 & .01 & -.01 \\
\hline $\begin{array}{l}\text { Office follows written clinical } \\
\text { guidelines for treating specific } \\
\text { conditions }\end{array}$ & .05 & .09 & .08 & .03 & -.00 \\
\hline \multicolumn{6}{|l|}{ Office Characteristics } \\
\hline Solo practice & .09 & -.01 & .01 & & .07 \\
\hline Primary group & -.07 & -.05 & -.05 & & .05 \\
\hline Multispecialty group & .04 & .06 & .06 & & .06 \\
\hline Number of physicians & .09 & $.11^{*}$ & .08 & & .02 \\
\hline Private ownership & .07 & .01 & .05 & & .01 \\
\hline Easy to refer & $.39^{* *}$ & $.37^{* *}$ & $.36^{* *}$ & & $.31^{* *}$ \\
\hline \multicolumn{6}{|l|}{ Physician Practice Characteristics } \\
\hline Patient visits per hour & .03 & .04 & & & .03 \\
\hline Administrative hours per week & -.09 & -.10 & & & -.09 \\
\hline $\begin{array}{l}\text { Percentage patients referred per } \\
\text { month }\end{array}$ & -.06 & .01 & & & .02 \\
\hline Percentage female patients & -.06 & $-.11^{*}$ & & & -.06 \\
\hline Percentage nonwhite patients & -.02 & $.11^{*}$ & & & .09 \\
\hline Percentage patients $\leq 18$ years & $-.10^{*}$ & -.02 & & & -.02 \\
\hline Percentage patients $\geq 65$ years & .08 & .10 & & & .05 \\
\hline $\begin{array}{l}\text { Percentage patients from middle- } \\
\text { or upper-class households }\end{array}$ & .06 & -.03 & & & -.01 \\
\hline \multicolumn{6}{|l|}{ Physician Characteristics } \\
\hline Female & -.08 & & & & .09 \\
\hline White & .04 & & & & .08 \\
\hline Family practice & -.01 & & & & .02 \\
\hline General practice & .08 & & & & .06 \\
\hline Board-certified & .06 & & & & .09 \\
\hline Years in practice & $.18^{\star *}$ & & & & .08 \\
\hline Tolerance for uncertainty & $.17^{\text {** }}$ & & & & $.18^{* *}$ \\
\hline
\end{tabular}

${ }^{*} P<.05$.

${ }^{* *} P<.01$

referrals (Table 2). However, this association was not significant in multivariable models controlling for practice and office characteristics (Table 4). Although a greater percentage of HMO patients and absence of a productivity bonus were associated with greater referral satisfaction (Tables 2 and 4), these associations were not significant after controlling for other characteristics (Table 4). 


\section{Physician, Practice, and Office Characteristics}

In bivariate analyses, referral satisfaction was highest for solo physicians, lowest for primary group physicians, and in-between for physicians in multispecialty groups. Physicians had greater referral satisfaction if they had more years of practice, had greater tolerance for uncertainty, worked fewer administrative hours, owned the practice, and thought it was easy to refer (Tables 2). In multivariable analyses, only 2 characteristics, ease of referral and greater tolerance for uncertainty, were associated consistently with greater referral satisfaction across models (Table 4).

\section{Discussion}

For primary physicians in the Seattle area, physician compensation, financial incentives, and care management tools were not associated generally with physicians' job and referral satisfaction. Bivariate analyses revealed initially that being a salaried employee, productivity bonuses, and withholds for referrals were associated with job and referral dissatisfaction. However, after controlling for physician, practice, and office characteristics, only the association between salary payment and job dissatisfaction remained significant.

Changes in physicians' practice arrangements may explain these findings. As managed care and market competition grew in the 1990s, so did the prevalence of group practices. ${ }^{4-49}$ Many primary physicians shifted-sometimes reluctantly-from solo to group practice and from being owners to being salaried employees. ${ }^{49}$ Compared with solo practice, large medical groups are more likely to be bureaucratic and to impose controls on the clinic and workload autonomy of their physician employees, mainly to reduce costs and improve quality of care. $^{34,48}$

The impact of these practice changes on physician job satisfaction are reflected in our results. We found that primary physicians are more dissatisfied in offices with a greater number of physicians, in group rather than solo offices, and when they do not own the practice. When we controlled for these office characteristics in multivariable analyses, financial incentives (a productivity bonus and referral withholds) were no longer associated with dissatisfaction, which suggests that the office characteristics are the source of the dissatisfaction. Salary payment was still associated with dissatisfaction, perhaps because employee physicians in group offices had less autonomy, and because this form of compensation limited physician incomes. These findings are consistent with our conceptual model (Figure 1).

We also found that care management tools were not associated with job or referral satisfaction. The finding is consistent with evidence that care management tools, by themselves, have little influence on practice behavior. ${ }^{50}$

Administrative hours, ease of referral, and tolerance of uncertainty also are determinants of physician satisfaction. Greater administrative hours, an indicator of bureaucratic medicine that may be associated with greater stress, was associated with physician job dissatisfaction, which is consistent with past studies. Ease of referral was associated with greater job and referral satisfaction. We suspect that ease of referral may be a proxy indicator for a "well-run" office that helps physicians practice medicine, manages their patient flows, and respects their clinical autonomy. Physicians with greater tolerance for uncertainty in patient care also have greater job and referral satisfaction, which is consistent with Freeborn's study of Kaiser Permanente physicians. ${ }^{12}$ Tolerance for uncertainty may be an important "buffer" that helps physicians cope with the inherent uncertainty of patient care, as well as managed care controls targeting physicians' clinical decisions.

Understanding the sources of physician dissatisfaction is important because dissatisfaction may have adverse effects on the cost, quality, and outcomes of care. ${ }^{35}$ Salaried employment in large medical groups may be a risk factor for physician dissatisfaction. In these settings, physician dissatisfaction can be reduced by installing administrative arrangements that protect clinical autonomy and offer reasonable work schedules and compensation. ${ }^{18,26}$ Similarly, physician job and referral satisfaction may be increased through medical school curricula and continuing education that increase tolerance for uncertainty in daily practice. This is particularly important with the growth of evidencebased medicine, which may actually increase the complexity of patient care and therefore the importance of this competency. ${ }^{51,52}$

\section{Limitations}

Our findings are limited to primary physicians in Seattle in 1997, and relationships between managed 
care and physician satisfaction may be different in other places and periods. Our results may be influenced by nonresponse to the physician survey, but the relatively low nonresponse rate reduces this problem. Our data are cross-sectional, and associations between variables may not be causal. Because our data come from a single market, we cannot examine the association between market characteristics and physician satisfaction. We did not measure all aspects of physicians' offices and practices that might be associated with physician satisfaction.

\section{Conclusions}

Office managed care was generally not associated with physician job or referral satisfaction. Of the physician compensation, financial incentive, and care management variables that we examined, only being a salaried employee was associated with physician job dissatisfaction. The number of physicians in the medical office had the strongest association with physician job dissatisfaction. These findings imply that the source of dissatisfaction is being an employed physician in a large medical group, which may be more likely to impose bureaucratic controls that limit physician autonomy. Primary physicians may have greater job satisfaction in smaller, less bureaucratic offices that protect their autonomy in work schedules and clinical decision-making.

\section{References}

1. Stoddard JJ, Reschovsky JD, Hargraves JL. Managed care in the doctor's office: has the revolution stalled? Am J Manag Care 2001;7:1061-8.

2. Murray A, Montgomery JE, Chang H, Rogers WH, Inui T, Safran DG. Doctor discontent: a comparison of physician satisfaction in different delivery system settings, 1986 and 1997. J Gen Intern Med 2001;16: 452-9.

3. Linzer M, Konrad TR, Douglas J, et al. Managed care, time pressure, and physician job satisfaction: results from the physician worklife survey. J Gen Intern Med 2000;15:441-50.

4. Kerr EA, Mittman BS, Hays RD, Zemencuk JK, Pitts J, Brook RH. Associations between primary care physician satisfaction and self-reported aspects of utilization management. Health Serv Res 2000;35: 333-49.

5. Hadley J, Mitchell JM, Sulmasy DP, Bloche MG. Perceived financial incentives, HMO market penetration, and physicians' practice styles and satisfaction. Health Serv Res 1999;34:307-21.

6. Collins KS, Schoen C, Sandman DR. The Commonwealth fund survey of physician experience with managed care. New York: Commonwealth Fund, 1997. Available at: URL: http://www.cmwf.org/ programs/health_care/physrvy.asp

7. Donelan K, Blendon RJ, Lundberg GD, et al. The new medical marketplace: physicians' views. Health Aff (Millwood) 1997;16:139-48.

8. Hadley J, Mitchell JM. Effects of HMO market penetration on physicians' work effort and satisfaction. Health Aff (Millwood) 1997;16:99-111.

9. Deckard GJ. Physician responses to a managed environment: a perceptual paradox. Health Care Manage Rev 1995;20:40-6.

10. Dugdale DC, Epstein R, Pantilat SZ. Time and the patient-physician relationship. J Gen Intern Med 1999; 14 Suppl 1:S34-40.

11. Bates AS, Harris LE, Tierney WM, Wolinsky FD. Dimensions and correlates of physician work satisfaction in a Midwestern city. Med Care 1998;36: 610-7.

12. Freeborn DK. Satisfaction, commitment, and psychological well-being among HMO physicians. West J Med 2001;174:13-8.

13. Melville A. Job satisfaction in general practice: implications for prescribing. Soc Sci Med [Med Psychol Med Sociol] 1980;14A:495-9.

14. DiMatteo MR, Sherbourne CD, Hays RD, et al. Physicians' characteristics influence patients' adherence to medical treatment: results from the Medical Outcomes Study. Health Psychol 1993;12:93-102.

15. Linn LS, Brook RH, Clark VA, Davies AR, Fink A, Kosecoff J. Physician and patient satisfaction as factors related to the organization of internal medicine group practices. Med Care 1985;23:1171-8.

16. Haas JS, Cook EF, Puopolo AL, Burstin HR, Cleary $\mathrm{PD}$, Brennan TA. Is the professional satisfaction of general internists associated with patient satisfaction? J Gen Intern Med 2000;15:122-8.

17. Buchbinder SB, Wilson M, Melick CF, Powe NR. Estimates of costs of primary care physician turnover. Am J Manag Care 1999;5:1431-8.

18. Warren MG, Weitz R, Kulis S. Physician satisfaction in a changing health care environment: the impact of challenges to professional autonomy, authority, and dominance. J Health Soc Behav 1998; 39:356-67.

19. Wagner EH. Clinical and outcomes research. HMO Pract 1994;8:54.

20. Baker LC, Cantor JC, Miles EL, Sandy LG. What makes young HMO physicians satisfied? HMO Pract 1994;8:53-7.

21. Baker LC, Cantor JC. Physician satisfaction under managed care. Health Aff (Millwood) 1993; 12(Suppl):258-70.

22. Chuck JM, Nesbitt TS, Kwan J, Kam SM. Is being a doctor still fun? West J Med 1993;159:665-9.

23. Schulz R, Scheckler WE, Moberg P, Johnson PR. Changing nature of physician satisfaction with 
health maintenance organization and fee-for-service practices. J Fam Pract 1997;45:321-30.

24. Blumenthal D, Causino N, Campbell EG, Weissman JS. The relationship of market forces to the satisfaction of faculty at academic health centers. Am J Med 2001;111:333-40.

25. Reschovsky J, Reed M, Blumenthal D, Landon B. Physicians' assessments of their ability to provide high-quality care in a changing health care system. Med Care 2001;39:254-69.

26. Barr D. The effects of organizational structure on primary care outcomes under managed care. Ann Intern Med 1995;122:353-9.

27. Wolinsky FD. Why physicians choose different types of practice settings. Health Serv Res 1982:17: $399-419$.

28. Shearer S, Toedt M. Family physicians' observations of their practice, well being, and health care in the United States. J Fam Pract 2001;50:751-6.

29. Williams ES, Konrad TR, Scheckler WE, et al. Understanding physicians' intentions to withdraw from practice: the role of job satisfaction, job stress, mental and physical health. Health Care Manag Rev 2001;26:7-19.

30. Williams ES, Konrad TR, Linzer M, et al. Physician, practice, and patient characteristics related to primary care physician physical and mental health: results from the Physician Worklife Study. Health Serv Res 2002;37:121-43.

31. Frank E, McMurray JE, Linzer M, Elon L. Career satisfaction of US women physicians: results from the Women Physicians' Health Study. Society of General Internal Medicine Career Satisfaction Study Group. Arch Intern Med 1999;159:1417-26.

32. Lammers JC. Work autonomy, organizational autonomy, and physicians' job satisfaction. Curr Res Occup Prof 1992;7:157-75.

33. Mick SS, Sussman S, Anderson-Selling L, et al. Physician turnover in eight New England prepaid group practices: an analysis. Med Care 1983;21:323-37.

34. Grumbach K, Osmond D, Vranizan K, Jaffe D, Bindman AB. Primary care physicians' experience of financial incentives in managed-care systems. N Engl J Med 1998;339:1516-21.

35. DeVoe J, Fryer GE, Hargraves JL, Phillips RL, Green LA. Does career dissatisfaction affect the ability of family physicians to deliver high-quality patient care? J Fam Pract 2002;51:223-8.

36. Grembowski D, Martin D, Patrick DL, et al. Managed care, access to specialists, and outcomes among primary care patients with depressive symptoms. J Gen Intern Med 2002;17:258-69.

37. Grembowski DE, Diehr P, Novak LC, et al. Measuring the managedness and covered benefits of health plans. Health Serv Res 2000;35:707-34.
38. 1995 National directory of HMOs. Washington, DC: Group Health Association of America, 1995.

39. American Medical Association. Physician Master File. Chicago, IL: American Medical Association, 1996.

40. Gerrity MS, DeVellis RF, Earp JA. Physicians' reactions to uncertainty in patient care: a new measure and new insights. Med Care 1990;28:724-36.

41. Greenfield S, Sullivan S, Kaplan S, Silliman R. Diabetes II- patient outcomes research team, physician questionnaire, section 3. Job and practice satisfaction. Boston, MA: New England Medical Center, 1992.

42. Shortell SM. Appendix C (physician questionnaire). In: A model of physician referral behavior: a test of exchange theory in medical practice. Chicago: Center for Health Administration Studies, University of Chicago, 1972.

43. Roulidis ZC, Schulman KA. Physician communication in managed care organizations: opinions of primary care physicians. J Fam Pract 1994;39:446-51.

44. Konrad TR, Williams ES, Linzer M, et al. Measuring physician job satisfaction in a changing workplace and a challenging environment. SGIM Career Satisfaction Study Group. Society of General Internal Medicine. Med Care 1999;37:1174-82.

45. Dillman DA. Mail and telephone surveys: the total design method. New York: John Wiley and Sons, 1978.

46. Dillman DA. Mail and Internet surveys: the tailored design method. 2nd ed. New York: John Wiley and Sons, 2000.

47. Grembowski DE, Cook KS, Patrick DL, Roussel AE. Managed care and the U.S. health care system: a social exchange perspective. Soc Sci Med 2002;54: 1167-80.

48. Gold M. The changing US health care system: challenges for responsible public policy. Milbank Q 1999;77:3-37.

49. Kletke PR, Emmons DW, Gillis KD. Current trends in physicians' practice arrangements: from owners to employees. JAMA 1996;276:555-60.

50. Lomas J, Andersen GM, Domnick-Pierre K, Vayda E, Enkin MW, Hannah WJ. Do practice guidelines guide practice? The effect of a consensus statement on the practice of physicians. N Engl J Med 1989; 321:1306-11.

51. Timmermans S, Angell A. Evidence-based medicine, clinical uncertainty, and learning to doctor. J Health Soc Behav 2001;42:342-59.

52. Fox R. Medical uncertainty revisited. In: Albrecht GL, Fitzpatrick R, Scrimshaw SC, editors. Handbook of social studies in health and medicine. London: Sage Publications, 2000;409-25 